\title{
Study Agent Status Code
}

National Cancer Institute

\section{Source}

National Cancer Institute. Study Agent Status Code. NCI Thesaurus. Code C94285.

A coded value specifying the phase in the lifecycle of the agent's association to a study. 